\title{
The Implementation of Education for Sustainable Development in Adiwiyata School
}

\author{
Yosi Nurira Adriyanto ${ }^{1}$, Dwi Nowo Martono ${ }^{1}$, Nadiroh $^{2}$, Tri Edhi Budhi Soesilo ${ }^{1}$ \\ \{yosi.nurira@ui.ac.id ${ }^{1}$,nowo2003@yahoo.com ${ }^{2}$, nadiroh@unj.ac.id ${ }^{3}$ \}
}

School of Environmental Science, Universitas Indonesia, Jl. Salemba Raya No. 4 Central Jakarta 10430 , Indonesia ${ }^{1}$, Faculty of Social Science, Universitas Negeri Jakarta, Jakarta, Indonesia ${ }^{2}$

\begin{abstract}
Education for Sustainable Development (ESD) provides a holistic perspective to act sustainably through activities directed to the community. The Adiwiyata program develops students' behaviour and through good school governance to support sustainable development but has several problems and obstacles including less understanding of the concept of an environmentally friendly school, lack of communication and human resources, and there is no statistical data on the environment perception or environmental awareness in Indonesia. This study aims to analyze school potencies in ESD implementation and expect Adiwiyata school to be able to contribute to the implementation of ESD in Indonesia. Six school leaders in Jakarta were interviewed to gather information on school potencies for the implementation of ESD in Adiwiyata schools. The results show that both schools have obstacles in the process of implementing policies and activities with the concept of sustainability even though they have the potencies to implement the ESD program.
\end{abstract}

Keywords: ESD, Adiwiyata, implementation, education, school

\section{Introduction}

The concept of Education for Sustainable Development (ESD) was developed by the UN General Assembly in 1987. The early concept of ESD disclosed in Chapter 36 out of 40 Chapter of Agenda 21, which states "Promoting Education, Public Awareness and Training" [1]. Education for sustainable development is an action taken to maintain the existence of human life itself by way of preserving the natural environment, social and cultural [2]. Education for Sustainable Development is a transformative pedagogy that challenges the interests and existing hegemonic structures because it is a learning process to live within ecological boundaries without human suffering that must include the expression of ideologies and power relations that underlie the discourse of sustainable development [3]. The welfare of individuals and communities that are inclusive and equitable is a normative goal adopted by ESD [4]. ESD is expected to highlight values and ethical issues related to the environmental, economic and social dimensions that focus on global challenges, both in the present and the future [5]. ESD attempts to balance human and economic well-being by respecting the diversity of culture and natural resources [6], and the preparation of the next generation for future sustainability, stable and developing social and economic, and will require multidisciplinary skills [7]. 
Providing a holistic and multi-perspective on the problem will deepen intuitive knowledge and clarify student emotions, reading literacy through the lens of sustainability will also inspire students to act sustainably and through an activity directly with the community. Through this way, students become connected to the community to share their knowledge and skills and become collaborators for the development of a sustainable and environmentally friendly society $[8,9]$. ESD theories and practices are made differently for primary and higher education. At the basic level, ESD is carried out to increase social and environmental awareness among children, while for vocational or higher level, ESD aims to further develop the knowledge and skills needed for green economy participation [10].

Adiwiyata school is a school that has implemented a system intending to realize school members who are responsible for environmental protection and management through good school governance to support sustainable development. The adiwiyata's program itself has been implemented by the Ministry of Environment and continued by the Ministry of Environment and Forestry which aims at creating schools that care for and are cultured in the environment through coaching, evaluating, and awarding to schools. The facts prove that the Adiwiyata program initiated by the government has several problems and obstacles. Several problems hamper the Adiwiyata program in several high schools in Malang; some students still do not understand the concept of environmentally friendly schools [11]. The implementation of Adiwiyata in SMAN 11 Semarang also did not go well due to lack of communication between the school and the person in charge of the program, and the human resource is still poor [12]. Almost no statistical data on the perception of the environment or environmental awareness in Indonesia, but this data is very important to know how the perceptions of students [13]. Depth of knowledge, attitudes, and behaviours that are owned by the citizens of the school applying Adiwiyata program are much higher when compared to the level of knowledge, attitudes, and behaviour of people in schools that do not apply Adiwiyata program [14]. The program related to ESD in West Nusa Tenggara Province (NTB) is the Adiwiyata School Program, but it is only adopted by schools that have excellent predicate in the urban area [15].

There is no systematically developed model for sustainable development of education in high schools in Indonesia. This research aims to analyze the school potencies, especially Adiwiyata recipient schools for the implementation of education for sustainable development.

\section{Methods}

The literature study was conducted to obtain material for compiling interview material which contains the school policy, the teaching and learning process in schools, school activities as the school potencies which have been mentioned in several published papers and integrated with Adiwiyata components and standards from the Indonesian Ministry of Environment and Forestry. Interviews were conducted to six school leaders in SMA Negeri 26 and SMA Negeri 42 Jakarta, which both schools are Adiwiyata Award recipient schools. School leaders in this study are the principal, vice-principal or person in charge of the Adiwiyata program, as well as the coordinator of activities related to environmental awareness. 


\section{Result and Discussion}

The strategies of instilling the values of ESD are implemented in schools through several learning strategies, including 1) subjects integration; 2) local content as a separate subject (monolithic); some schools carry out local content in environmental education which only focuses on environmental perspective; 3) extracurricular activities / personal development programs; 4) habit (acculturation) as the application of the vision and mission of the school, including the implementation of school regulations [16, 17]. The application of ESD in planning, policy development, implementation, curriculum, and school management can enable citizens to act for better and sustainable environmental and social change through education [18]. ESD curriculum development can use the principles of appreciation for nature, nature care, the use of healthy lifestyles and sustainable living practices [19]. The ESD integration approach (education for sustainable development) in the document of "Criteria for ESD-Schools (Guidelines to enhance the quality of Education for Sustainable Development)" explains that involvement in ESD should not be considered as an additional burden on teachers and principals. The document also mentions that this integrated approach is used as an opportunity to improve teaching and learning activities, and to improve innovation for all schools [20]. There are three quality criteria used for the ESD integration approach in the school environment:

a. Criteria regarding the quality of the teaching and learning process: areas of teaching and learning approach, areas of results seen in schools and in local communities, areas of perspective for the future, areas of cultural complexity, areas of critical thinking and linguistic possibilities, areas of clarification and value development, areas of action-based perspective, area of participation, and area of subject matter;

b. Criteria regarding school policies and organizations: areas of school policy and planning, areas of school climate, areas of school management, areas of reflection and evaluation of ESD initiatives at the school level;

c. Criteria regarding school external relations: areas of community cooperation, areas of network and partnerships [20].

From the literature study above, the authors use the school policy mentioned by Nuamcharoen \& Dhirathiti, the teaching and learning process in schools, and school activities from Breiting et al., as well as integration with Adiwiyata's standard components to produce the concept of school potencies that is used as a reference for conducting interviews. The concept of school potencies can be seen in the following Table 1.

Table 1. Concepts of school potencies in implementing ESD.

\begin{tabular}{|c|c|c|}
\hline School policy & $\begin{array}{l}\text { Teaching and learning process } \\
\text { in schools }\end{array}$ & School activity \\
\hline 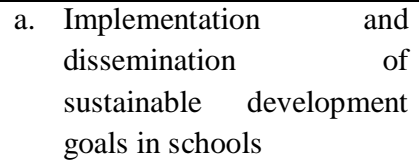 & $\begin{array}{l}\text { a. Teachers' understanding of } \\
\text { sustainable development; } \\
\text { b. Integrating sustainable } \\
\text { development goals into }\end{array}$ & $\begin{array}{l}\text { a. Student activities related to } \\
\text { environmental concerns that } \\
\text { are sustainable (co-curricular } \\
\text { and extracurricular); }\end{array}$ \\
\hline
\end{tabular}




\begin{tabular}{|c|c|c|}
\hline $\begin{array}{l}\text { b. School management of } \\
\text { climate and environmental } \\
\text { friendly-based }\end{array}$ & $\begin{array}{l}\text { subjects; } \\
\text { c. Methods of teaching and } \\
\text { learning activities. }\end{array}$ & $\begin{array}{ll}\text { b. } & \text { School collaboration with } \\
\text { non-school institutions } \\
\text { (NGOs, universities, and } \\
\text { other institutions). }\end{array}$ \\
\hline
\end{tabular}

Therefore, the focus of this research discussion is on school policy and school activities. In this study, respondents were given several questions developed from the concepts above related to school policy consisting of nine questions and school activities consisting of six questions. They were given questions related to school policies and school activities:

a. School policy

Following the vision and mission of schools as Adiwiyata recipient schools, the two schools have not implemented a written curriculum structure regarding Sustainable Development Goals (SDGs), because there are no instructions and dissemination from the government and related agencies in this case the Education Office (Dinas Pendidikan). Even though SDG's have not been implemented in the curriculum structure, the programs conducted in the two schools have headed towards it. Some subjects have integrated and implemented to apply the concepts of environmental sustainability developed by the teacher of related subjects. Familiarizing activities for students and the application of learning designs carried out by the teacher in the subject is the first step taken by the principals in implementing curriculum structures for SDG's proponents. Indicators and instruments for evaluating sustainability are already in the long-term plan of SMA Negeri 26, but the long-term plan is only for four years so it needs to be prepared, and re-evaluated following the school program. The indicators and instruments have also been disseminated to the school community including students and parents so that all school components can support long-term sustainable school plans. Environmental learning plans have been prepared in the form of Standard Operational Procedures (SOPs) involving all lines and components of the school including students, teachers, and administration. In the preparation of learning designs in SMA Negeri 42, each subject must include environmental content in the material. There are no special environmental subjects, but it is integrated with other subjects.

The application of environmental knowledge to environmental learning in both schools has led to the concept of sustainability and has minimized environmental problems at school on a small scale. The greening program, the establishment of a greenhouse, the planting of family medicinal plants ( $\operatorname{tog} a$ ), the utilization of a drainage channel for fish, the development of a literacy corner with garden in SMA Negeri 26 became an annual program implemented at the school. Different with SMA Negeri 42, the effort to provide education to students is not only on environmental issues, but also the problem of bullying, and other social problems addressed in the students' council (OSIS) for leadership basic training program. Providing education for social issues is a program that can be implemented to support ESD programs in schools because the goal of sustainable development does not only consist of environmental aspects but also social and economic aspects.

Waste bank management has also been carried out at SMA Negeri 26 (Figure 1) as an activity of innovation and creativity of school residents in supporting sustainable waste management after being inactive because of the limitations of equipment and lack of human resources. The results of the management of this waste bank produce dry fertilizer which is used to fostering plants that are in the school environment. The utilization of waste and recycling of used goods is one of the agenda of activities that are routinely carried out in SMA Negeri 42. This is as stated by Mr. Sony Juhersoni as the Head of SMA 42 Jakarta as follows: 
"Sekarang sampah tidak lagi dibuang, jangan membuang sampah itu sudah menjadi paradigma lama, sekarang bagaimana sampah itu kemudian kita manfaatkan dan dikelola untuk menjadi sebuah hal yang bermanfaat"

(Now garbage is no longer thrown away, "no littering" statement has become an old paradigm, now how the waste is used and manages to be a useful thing) [21].

b. School activity

Participation and collaboration of parents and student's guardians with schools in both schools have been going well. One of the contributions of parents and guardians is to support school greening, make RKAS (School Activity and Budget Plan) which is hosted by the School Committee. This is as conveyed by Ms. Sri Sariwarni as the head of SMA 26 Jakarta as follows:

“..kita selalu melaksanakan kegiatan-kegiatan sekolah pasti kita libatkan, sampai yang namanya penyusunan RKAS pun pasti kita libatkan orang tua, jadi kita memang open management.."

(... we always carry out school activities, we will involve it such as the preparation of the RKAS, we will certainly involve the parents, so we are indeed open management ...) [22].

Company participation involving school residents in environmental action activities carried out at schools of which is the "Plastic Reborn" activity in which the company provides a special trash bin for plastic and bottle cap utilization activities in making murals in schools. Form of participation of both schools in providing education and the promotion of environmental preservation was through the establishment of target schools. The participation of the two schools in the target schools was carried out for environmental action, coaching, exchanging information on environmental issues, and a courtesy call to see the Adiwiyata culture in the target schools.

Partner cooperation in environmental action and social environment is also carried out by school residents to increase environmental awareness and social care of citizens of SMA Negeri 26 and SMA Negeri 42 Jakarta. The policy of one student to plant one tree and join Clean Up Jakarta Day (CUJD) is a form of action of the participation of citizens of SMA Negeri 26 Jakarta in protecting the environment. SMA Negeri 42 students collaborated with one of the NGOs (non-governmental organizations) for beach cleaning in the Ancol area and cleaned up trash in the river. Collaboration with government institutions and organizations was also carried out for disaster response preparation, creating gathering points, evacuation routes and drilling for natural disasters. Collaboration with the Ministry of Environment and the sub-district had been carried out in the management of the waste bank. The Puskesmas (Public health centre) held a socialization event in realizing a healthy environment. Students had to be able to solve problems related to the prevention of natural disasters, for example, floods.

Decision making on school policies made by school leaders is inseparable from constraints. The obstacles encountered can be from inside and outside the school. The funding factor was one of the main factors in decision making for the policy and implementation of school activities. The school had provided a special budget to carry out all activities related to the development of environmental awareness, but large funds were still needed. Many companies through CSR (corporate social responsibility), provide support to both schools in the implementation of environmental awareness activities. Limited time is also an obstacle for both schools because schools are not permitted to subtract school hours so that the school must be truly effective in choosing activities. SMA Negeri 42 experienced some constraints, namely the achievement of participation of school members, teacher rotation, and new students who are still adapting to the environmental culture at school. SOPs implementation of the learning 
environment in SMA Negeri 26 there is obstacles that include lack of caraka. In this case, the teaching force where educators in SMA Negeri 26 adjusts local government regulations with the ratio of class sizes so that it cannot be directly proportional to the study groups in SMA Negeri Negeri 26 to fulfill and maximize environmental learning at school. The external constraints are including the stakeholders and the bureaucratic ranks of the government and institutions that overshadow the two schools that have not fully supported and participated in environmental culture.

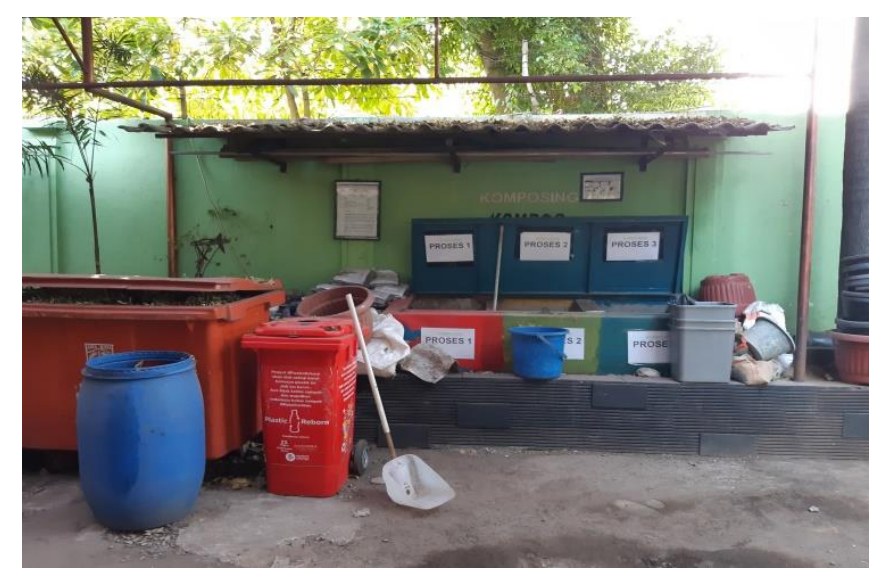

Fig. 1. Waste bank management and compost processing in SMA Negeri 26 Jakarta.

\section{Conclusion}

The guidelines for implementation of the Adiwiyata program are regulated by the Minister of Environment Regulation fifthly of the Year 2013. The implementation of the Adiwiyata program is laid down in a participatory principle (all school components are involved) and sustainability with all activities carried out in a planned and comprehensive manner [23]. SMA Negeri 26 as the National Adiwiyata recipient school and SMA Negeri 42 Jakarta as the Adiwiyata Mandiri receiving school have great potencies to implement the education for sustainable development programs. The advantage of both schools as Adiwiyata recipients is that the school excels in the implementation of environmental learning and development. Although the government, in this case, the Education Office, has not yet provided direct information and instruction, both schools have comprehensively implemented the concept of sustainability in school policies and activities. The model of sustainable development learning is something that must be considered to support the potencies of schools in implementing ESD. So, according to Prabawa-Sear (2018) which states that the Adiwiyata Program can be used to develop students' responsible attitudes to protect and manage the natural environment through school governance that supports sustainable development [24].

Acknowledgment. This paper is supported and funded by the International Indexed Publication Grant for Student Final Project (PITMA B) by the University of Indonesia 2019. 


\section{References}

[1] UNESCO: Education for Sustainable Development Toolkit (2006)

[2] Segara NB.: Education for Sustainable Development (ESD) Sebuah Upaya Mewujudkan Kelestarian Lingkungan. SOSIO DIDAKTIKA: Social Science Education Journal, 2(1). (2015)

[3] Stevenson RB.: Tensions and transitions in policy discourse: Recontextualizing a decontextualized EE/ESD debate. Environmental Education Research,12(3-4) pp. 277-290. (2006)

[4] Nambiar P. Sarabhai KV.: Challenges that Lie Ahead for ESD. Journal of Education for Sustainable Development 9(1) pp. 1-3. (2015)

[5] Franck O. Osbeck C.: Challenging the concept of ethical literacy within Education for Sustainable. Development (ESD): Storytelling as a method within sustainability didactics. Education 3-13,46(2) pp. 133-142. (2016)

[6] Kadji-Beltran C, Christodoulou N, Zachariou A, Lindemann-Matthies P, Barker S, Kadis C.: An ESD pathway to quality education in the Cyprus primary education context. Environmental Education Research,23(7) pp. 1015-1031. (2016)

[7] Fahey S, Verstraten L, Berry AJ.: Education for Sustainable Development: Enhancing Climate Change Adaptation Expertise in Developing Countries. Journal of Education for Sustainable Development, 10(1), pp. 54-67. (2016)

[8] Down L.: Engaging Mindfully With the Commons: A Case of Caribbean Teachers' Experience With ESD. Applied Environmental Education \& Communication,14(2), pp. 105-111. (2015)

[9] O'Brien C, Howard P.: The Living School: The Emergence of a Transformative Sustainability Education Paradigm. Journal of Education for Sustainable Development, 10(1), pp. 115-130. (2016)

[10]Kopnina H.: Education for sustainable development (ESD): The turn away from 'environment' in environmental education. Environmental Education Research,18(5), pp. 699-717. (2012)

[11] Landriany E.: Implementasi kebijakan adiwiyata dalam upaya mewujudkan pendidikan lingkungan hidup di SMA Kota Malang. Jurnal kebijakan dan pengembangan pendidikan, 2(1). (2014)

[12] Iswari RD, Utomo SW.: Evaluasi Penerapan Program Adiwiyata Untuk Membentuk Perilaku Peduli Lingkungan di Kalangan Siswa (Kasus: SMA Negeri 9 Tangerang Selatan dan MA Negeri 1 Serpong). Jurnal Ilmu Lingkungan, 15(1), 35. (2017)

[13] Parker L, Prabawa-Sear K., Kustiningsih W.: How young people in Indonesia see themselves as environmentalists. Indonesia and the Malay World,1-20. (2018)

[14] Tompodung TC, Rushayati SB, Aidi MN.: Efektivitas Program Adiwiyata Terhadap Perilaku Ramah Lingkungan Warga Sekolah Di Kota Depok. Jurnal Pengelolaan Sumberdaya Alam Dan Lingkungan (Journal of Natural Resources and Environmental Management), 8(2), pp. 170-177. (2018)

[15]Sutanto HP.: Education for Sustainable Development Situations in the West Nusa Tenggara Province. Cakrawala Pendidikan, 36(3). (2017)

[16] Listiawati N.: Pelaksanaan Pendidikan untuk Pembangunan Berkelanjutan oleh Beberapa Lembaga. Jurnal Pendidikan dan Kebudayaan, 19(3), pp. 430-450. (2013)

[17] Laurie R, Nonoyama-Tarumi Y, Mckeown R., Hopkins, C.: Contributions of Education for Sustainable Development (ESD) to Quality Education: A Synthesis of Research. Journal of Education for Sustainable Development,10(2), pp. 226-242. (2013)

[18] Nuamcharoen S, Dhirathiti NS.: A case study of the co-production approach to the implementation of education for sustainable development in Thailand. Policy Futures in Education, 16(3), pp. 327-345. (2017)

[19] Bhagwanji Y, Born P.: Use of Children's Literature to Support an Emerging Curriculum Model of Education for Sustainable Development for Young Learners. (2018)

[20] Breiting S, Mayer M, Morgensen F.: Quality criteria for ESD-schools: Guidelines to enhance the quality of education for sustainable development. Vienna: Austrian Federal Ministry of Education, Science and Culture.( 2005)

[21] Juhersoni, Sony:. Interview (2019)

[22] Sariwarni, Sri.: Interview (2019) 
[23] Maryani I.: Evaluasi Pelaksanaan Program Sekolah Adiwiyata Ditinjau dari Aspek Kegiatan Partisipatif di SDN Ungaran I Yogyakarta. Jurnal Pemikiran dan Pengembangan Sekolah Dasar (JP2SD), 1(3), pp. 170-180. (2016)

[24] Prabawa-Sear K. Winning Beats Learning. Indonesia and the Malay World,1-20. (2018) 